\title{
RENT DEREGULATION, TENURE CHOICE, AND REAL ESTATE PRICE EXPECTATIONS
}

\author{
Ashot Tsharakyan \\ Petr Zemčík
}
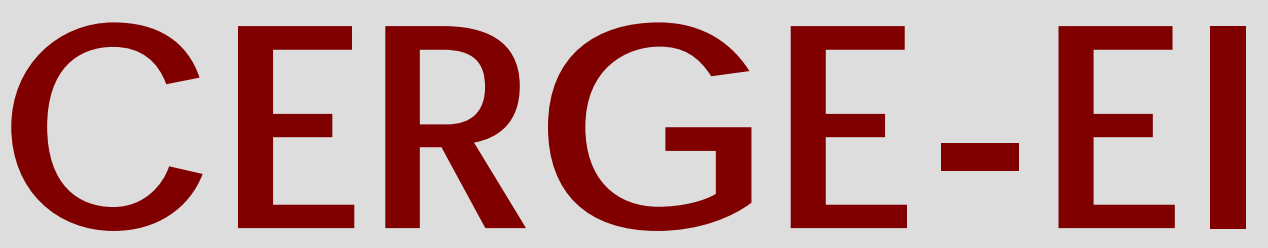

Charles University Centerfor Economic Research and Graduate Education Academy of Sciences of the Czech Republic Ec onomic s Institute 


\title{
Working Paper Series (ISSN 1211-3298)
}

\section{Rent Deregulation, Tenure Choice, and Real Estate Price Expectations}

\author{
Ashot Tsharakyan
}

Petr Zemčík

CERGE-EI

Prague, January 2011

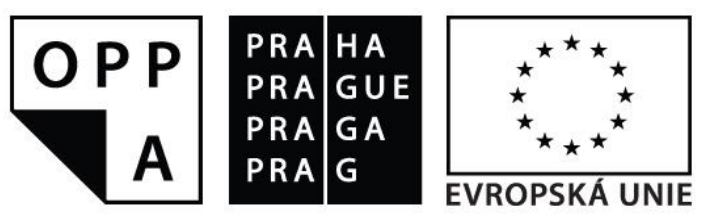

EVROPSKÝ SOCIÁLNÍ FOND

PRAHA \& EU: INVESTUJEME DO VAŠÍ BUDOUCNOSTI 
ISBN 978-80-7343-231-7 (Univerzita Karlova. Centrum pro ekonomický výzkum a doktorské studium)

ISBN 978-80-7344-221-7 (Národohospodářský ústav AV ČR, v.v.i.) 


\title{
Rent Deregulation, Tenure Choice, and Real Estate Price Expectations
}

\author{
Ashot Tsharakyan and Petr Zemčík* \\ CERGE-EI, Prague ${ }^{\dagger}$
}

January, 2011

\begin{abstract}
We study a natural experiment in the Czech Republic where the maximum regulated rent appreciation has depended explicitly on the price of real estate since 2007. We track the tenure choice of households from consumption surveys for subsequent years. Rent deregulation makes households in regulated apartments more likely to own real estate while the opposite is true for other renters and owners. The net present value of buying property vs renting is an increasing function of the real estate price appreciation for renters in regulated apartments. We use their tenure choice to generate the distribution of property price expectations.
\end{abstract}

\begin{abstract}
Abstrakt
Studujeme přirozený experiment v České Republice, kde byl od roku 2007 stanoven maximální růst regulovaného nájemneho. Tento růst je explicitní funkcí realitní ceny. Sledujeme volbu domácností mezi vlastním a nájemným bydlením v čase $\mathrm{s}$ použitím statistiky rodinných účtů. Díky deregulaci nájemného si domácnosti v regulovaných bytech častěji pořizují vlastní bydlení. Opak je pravdou pro domácnosti ve vlastních bytech a v nájemních bytech s neregulovaným nájemným. Čistá současná hodnota srovnávající bydlení ve vlastním a nájemném bytu je pro nájemníky v regulovaných bytech rostoucí funkcí růstu cen nemovitostí. Můžeme tak využít reálnou volbu těchto domácností na charaktersitiku rozdělení očekavaní budoucího růstu realitních cen.
\end{abstract}

KEY WORDS: Czech Republic; Expectations; Rent regulation and deregulation; Real estate prices; Tenure choice

JEL CLASSIFICATION: C25, R21, R31

*Ashot Tsharakyan acknowledges support from the Global Development Network. Petr Zemčík received funding from the European Community's Seventh Framework Programme (FP7/2007-2013) under Socio-economic Sciences and Humanities, grant agreement no 217466 and from the Czech Science Foundation project 402/09/1755.Correspondence address: Petr Zemčík, CERGE-EI, PO Box 882, Politickych veznu 7, 11121 Prague 1, Czech Republic. Email: petr.zemcik@cerge-ei.cz. We are thankful to Laura Straková for English editing. All errors remaining in this text are the responsibility of the authors.

${ }^{\dagger}$ CERGE-EI is a joint workplace of the Center for Economic Research and Graduate Education, Charles University, and the Economics Institute of the Academy of Sciences of the Czech Republic. 


\section{Introduction}

A large number of rental markets are characterized by a certain degree of rent regulation.

A simple non-targeted rent regulation consists of setting upward ceilings on the rent level. This type of rent regulation was common prior to the year 2000 in many countries of Central and Eastern Europe. After 2000, some countries such as Bulgaria and Estonia abandoned the practice and others, such as Poland, significantly reformed this policy. The Czech Republic was slow to follow this trend and introduced its plan for rent deregulation only in 2006, two years after it joined the European Union (EU). The plan aimed to reach a target rent given by $5 \%$ of the market real estate price by 2010; after 2010, rents would be completely deregulated. Prior to 2010, a law set the maximum annual appreciation for regulated rents, which explicitly depended on the market property price. This feature makes it very convenient to investigate the impact of the deregulation process on the tenure choice of households and enables us to deduce real estate price expectations of households living in rent-regulated apartments based on their choice between renting and owning.

Using mainly theoretical arguments and data on housing units, rent regulation has been shown to have both adverse and positive effects. ${ }^{1}$ Under pressure from the European Union, the Czech executive and legislative powers started the process of deregulation. This implied a tacit acceptance that the negative effects of rent regulation in the Czech

\footnotetext{
${ }^{1}$ Rent regulation affects real estate vacancies, household welfare, mobility and housing affordability. Moon and Rapoport (1997) use longitudinal Housing and Survey data from New York and find that a rent-controlled apartment is less likely to be vacant. Annas (1997) shows that rent regulation welfare improvements over laissez-faire only occur if gains from centralized matching can offset the decrease in housing quality, the possible increase in waiting times, and the risks of rationing induced by rent controls. Raess and Von Ungern-Sternberg (2002) study the impact of tenancy rent control for short-term contracts, which limits the owners possibilities to increase rents for a certain number of years. This type of rent control leads to lower equilibrium rents and higher social welfare. Munch and Svarer (2001) find that the presence of rent regulation on the private Danish housing market negatively affects a household's mobility. Simmons-Mosley and Malpezzi (2006) use panel data from the New York City Housing and Vacancy Survey and find a significant impact of benefits of lowered rent and costs of distortions in housing consumption on mobility. The costs are larger than the benefits. Lux (2001) compares the development of the social housing sector in the Czech Republic, Poland and Slovakia during the 1990s and concludes that maintenance of non-targeted rent regulation in the Czech Republic and Slovakia worsened the affordability of housing for low-income households.
} 
Republic were greater than the positive effects. While the impact of various types of deregulation has been studied, ${ }^{2}$ the Czech process is distinctive because of its simple design, explicit consideration of the market real estate price, and nationwide coverage. Moreover, the impact of sequential rent deregulation can be analyzed ex-post thanks to the availability of household level data.

Our primary focus is on how rent deregulation affects the tenure choice of households, i.e. the decision to own vs. to rent. This aspect of deregulation has been neglected in the literature. We quantify the degree of deregulation in two ways, depending on the current status of a household. If the household rents a regulated apartment, the maximum annual rent appreciation serves as a measure of deregulation. An increase in rental costs implies either the necessity to pay higher rent closer to free market rent or to switch to owning instead of renting. If the household currently pays market rent or owns its dwelling, our measure of deregulation is the ratio of the number of regulated apartments to the number of all rented apartments. This measure reflects the anticipation that previously regulated housing units would soon increase the supply of unrestricted rental housing. Lux and Sunega (2003) show that this would lead to a decrease of free market rents in the Czech Republic. Lower market rents should translate into a lower likelihood of being an owner in the next period.

We further control for standard household characteristics such as income, age, education, and size, and also consider two additional variables of interest. The first is interest rate calculated by approximating output from a mortgage calculator. The second is the real estate price prevailing in the household's location. Li and Yao (2005) build a life-cycle

\footnotetext{
${ }^{2}$ Roistacher (1992) analyzes three possible forms of partial rent deregulation on the New York City rental market: income-targeted decontrol, high-rent decontrol and vacancy decontrol. She finds that a combination of income-targeted decontrol and vacancy decontrol seems the best option for reforming New York City's rent regulation system and would generate substantial new taxable rental income. Van der Klaauw and Kock (1999) develop a static partial equilibrium model to investigate deregulation of the Dutch housing market on private market prices and allocations of houses among households. They focus on three regulation measures: individual rent, supporting social housing projects, and social rules for owner-occupied houses. They conclude that there are potential welfare gains as a result of simultaneous deregulation of the owner occupied and the rental segments of the Dutch housing market.
} 
model to show that higher property prices reduce the welfare of renters and increase the welfare of older owners. We concentrate on changes in the probability of owning due to changes in property prices.

We employ a unique dataset for Czech households. It is based on a series of budgetary surveys in a rotating sample where only some $25 \%$ of households are replaced each year. By using this feature of the data we can follow a particular household for two years in a row and see if its status remained the same or changed during this period: renters living in regulated apartments can become owners or renters for market rent; renters paying market rent can become owners; owners can become renters on the free rental market. We record the tenure choice between years $t$ and $t+1$ and construct datasets for periods 2005-6, 2006-7, and 2007-8, respectively. This approach differs from the prevailing cross-sectional analysis. For example, Beck, Kibuuka, and Tiongson (2010) employ data from the European Union Statistics on Income and Living Conditions (SILC). This is a series of cross-sections between 2005-2007 from old and new member countries of the EU. ${ }^{3}$ This study finds it difficult to explain households' tenure choice, which may be due to the inability to follow households over time. In contrast, our data enables us to see actual choices made by households. The effect of rent deregulation on tenure choice is analyzed using standard models of limited dependent variables. Our results demonstrate that appreciating regulated rents make households living in regulated apartments seek other alternatives more frequently. As expected, increasing regulated rents decrease the probability of owning for renters on the unregulated market. Rent deregulation makes current owners more likely to sell their apartment and to rent since the market rent is expected to decrease.

In the next step, we exploit the specific nature of the Czech deregulation law to characterize real estate price expectations for households living in apartments with regulated rents. For these households, the present value of renting depends on the growth rate of

\footnotetext{
${ }^{3}$ Note that the SILC data are collected in the Czech Republic as well, in parallel with the sample used in this paper.
} 
regulated rents, which in turn depends explicitly on property prices. The only source of uncertainty is the price process. A similar scenario holds for the present value of property purchase, which takes into account the fact that property can be sold in the future. Households in regulated apartments compare the present value of owning with the present value of renting a regulated apartment. Using the fact that regulated rents explicitly take into account real estate prices, and assuming that these follow an $\mathrm{AR}(1)$ process, we solve for the real estate price appreciation, which makes households indifferent between an apartment purchase and renting. This appreciation is the upper bound for expectations of the households which remained renters and the lower bound for households which did not. The distributional characteristics of the price appreciation are more realistic when we assume that households mainly consider holding their potentially acquired property until a mortgage is paid off. The implied upper bound for expected real estate price growth was on average $1.8 \%$ in $2006-7$ and $2.3 \%$ in $2007-8$. The implied lower bound was on average $2.2 \%$ in the same two sub-periods. This indicates that household expectations were fairly realistic at the time, showing no signs of irrationality.

Research papers which explicitly deduce or survey expectations regarding real estate prices are scarce. Two exceptions close to our study are Case and Shiller (2004) and Clayton (1997). The former paper includes a survey of real estate price expectations of recent home buyers in four US counties and finds unrealistically high expected annual rates of growth for real estate prices. The selection in Case and Shiller (2004) consists of households which recently purchased real estate property. In our case, we focus on renters living in apartments with regulated rents and distinguish between those who opted for owning and those who did not. Clayton (1997) focuses on the implications of the present value model, which resembles our approach. He shows that there is a negative correlation between an ex-post house price appreciation and the forecast of risk-neutral agents, which rejects the null hypothesis of rational expectations. Unlike us, Clayton (1997) uses data on condominiums in the Vancouver metropolitan area rather than on households. 
The rest of the paper is organized as follows. Section 2 describes the evolution of rent regulation in the Czech Republic, section 3 describes the data used, and section 4 formulates an econometric model for tenure choice and discusses empirical results. Section 5 deduces real estate price expectations and section 6 concludes.

\section{Regulation of Rents in the Czech Republic}

In the Czech Republic, the permanent right to live in an apartment with low regulated rents was established in the 1980s. This right cannot be rescinded and can be passed only to a family member. It applies to a particular apartment, which makes it very hard to evict current tenants. Such a regulation has made part of the housing stock inaccessible for new tenants and has created a shortage of rental housing, since regulated apartments constitute around $80 \%$ of the housing stock on the rental market. As a result, free market rents have rapidly appreciated and a substantial gap has appeared between them and the regulated rents. The presence of two distinct segments of rental housing with considerably differing rents appears unjust from the social perspective and has generated public concern. Moreover, since regulated rents explicitly depend only on location and size of the dwelling, and the right to live in a regulated rent apartment was assigned 20 years ago, in many cases regulated rents do not reflect the social status and income of the tenants (see Lux, Sunega, Kostelecký, and Čermák 2003).

Many municipal regulated apartments were either returned to their original owners in the restitution process during the 1990s or were sold to private owners in the early 2000s. The low level of regulated rents, however, did not allow the owners to cover maintenance costs. In the early 2000s, the Czech Constitutional Court ruled in favor of owners on a number of occasions. In its decisions, the Court approved that an owner was allowed to find a compensatory rental apartment for the tenant, with a rent corresponding to the free rental market level. The main justification for these decisions was the outdated nature of a regulation based on the Ministry of Finance Bill 176 from 1993. The Czech government 
repeatedly attempted to legally reinstate this old regulation via formally new legislation, trying to sidestep the rulings of the Czech Constitutional Court. The Ministry of Finance for example, tried to freeze rent levels via a Bill 567 in 2002, which was also struck down by the Constitutional Court. The position of the Czech government was later affected by the international case Hutten-Czapska vs Poland, which was heard at the European Court of Human Rights in Strasbourg. The plaintiff claimed the right to collect a rent sufficient to at least cover the costs related to real estate. This case ended in 2008 with a friendly settlement. In light of this court case and due to rising public concern about the consequences of rent regulation, the Act 107 of Unilateral Rent Increase was proposed and approved in 2006. The Act specified a gradual increase of in regulated rent from 2007 to 2010 .

One of the most important features of Act 107 was that the regulated rent level and rent appreciation rates became explicitly dependent on actual apartment prices. These prices reflected apartment price indices calculated by the Czech Statistical Office (CSO) based on transaction real estate prices, which were available from the Ministry of Finance. ${ }^{4}$ This played a crucial role in the subsequent evolution of regulated rents since starting from 2006, the housing price appreciation rate in the Czech Republic increased considerably (see Figure 1). This led to an increase in regulated rents and a reduction in the gap between free market rents and regulated rents. This is likely to have had an immediate effect on the tenure choice of households living in regulated apartments since the cost of staying in those apartments was now greater. Indirectly, there should be an impact on other types of households as well.

The Act specifies the target rent and the maximum annual percentage increase for the years 2007-2010. Specifically, the target regulated rent is given by

$$
T_{t}=\frac{1}{12} c P_{t}
$$

where $T_{t}$ is the regulated monthly rent in Czech koruna per $1 \mathrm{~m}^{2} \mathrm{c}$ is the coefficient

\footnotetext{
${ }^{4}$ The Ministry of Finance collects this information because there is a $3 \%$ sales tax on real estate.
} 
reflecting the ratio of the annual rent to the price for a given apartment. $c=0.05$ for apartments of higher quality, previously referred to in the Czech Republic as apartments of the 1 st and 2 nd categories. $c=0.045$ for apartments with lower quality, i.e. apartments of the $3 \mathrm{rd}$ and 4 th categories in the previous classification. $P_{t}$ is the price per $1 \mathrm{~m}^{2}$, which is published by the Czech Ministry for Regional Development. The maximum annual percentage increase is calculated as

$$
M_{t+w}=100\left(\left(T_{t+w-1} / R_{t+w-1}\right)^{\frac{1}{4-w+1}}-1\right)
$$

where $w=1$ for 2007, 2 for 2008, 3 for 2009, and 4 for 2010, respectively. $R_{t+w-1}$ is the regulated rent at time $(t+w-1)$. The formula is constructed to make the regulated rent equal to the target rent in 2011, assuming that the real estate price does not change.

\section{Data}

The data used in this paper are extracted from Family Accounts of the Czech Household Budget Survey for the years 2005-2008. This survey includes 3200+ households each year. 71-78\% of the sample remains the same - see Table 1 for details. This feature makes it different from the EU-Statistics on Income and Living Conditions, which is a series of cross-sections, with a random sample drawn each year. The fact that only up to $1 / 4$ of the sample of households is replaced enables us to record households' tenure choice between years $t$ and $t+1$. The consumption survey data is complemented by real estate prices from the Czech Statistical Office, which is also published by the Czech Ministry of Regional Development.

Information about the type of rental apartment has been available only since 2006. In 2005, we had to separate households living in apartments with regulated vs. unregulated rents based on a comparison of reported rents with market rents from the Institute of Regional Information in Brno. Actual rents significantly lower than market rents corresponded to regulated apartments. However, in smaller cities the regulated rents were 
fairly close to market rents and we could not decide to which group we should assign a given household. We therefore excluded these households from our 2005-2006 sample. Table 1 characterizes the sub-samples by the ownership types of the households. $21-23 \%$ of the sample represent renters, and from this number on average about $81-84 \%$ are renters in apartments with regulated rent. The rest of the sample are owners. The number of households is somewhat reduced in the last sub-epriod do to a coding change in one of the regions, which made it harder for us to identify households remaining in the sample. Note that households in apartments with regulated rents can, in addition, switch to renting for the market rent. This can occur if they cannot afford the regulated rent and do not have a sufficient income and/or savings to purchase their own property. They are also not likely to qualify for a mortgage, especially if they are already retired. The ratio of households switching to owning among renters in regulated apartments increases from 5\% for the period 2005-6 to $14 \%$ in 2006-7. This illustrates that Act 107 had an immediate impact on tenure choice. The ratio of households moving from regulated to unregulated apartments is very small, $1-2 \%$. Only $2-3 \%$ of owners become renters again. Two-year panels are constructed for each group. For example, we use the data on households living in apartments with regulated rents in 2005, which also remained in the sample in 2006. A similar approach is used for the other groups and the remaining years.

We make use of a number of variables characterizing each household. The first group includes income per person, age and education of the household head, and the number of household members. The remaining variables are related to real estate: mortgage interest rate, regional real estate price, maximum regulated rent appreciation for households paying regulated rent, and the percentage of regulated apartments on the regional rental market for households paying the market rent. Table 2 provides summary statistics for renters and Table 3 for owners. The monthly income per household member in Czech crowns (Kč) is always higher for households in regulated rental apartments than for households in unregulated ones, which confirms that rent regulation does not help poorer 
households as initially intended. Households in regulated apartments are also somewhat older and slightly more educated as compared to the other renters. Owners have on average the highest income and age from all considered groups. The number of household members is a proxy for needed space and/or a measure of the need for stability attached to ownership. ${ }^{5}$ The first five variables measure the ability of a household to accumulate the necessary wealth to purchase real estate and/or to qualify for a mortgage. Similarly to other countries, banks in the Czech Republic provide mortgages in two steps. In the first step, the size of a maxiumum mortgage loan is determined. This depends on how much a household can afford to pay monthly, which is the amount that a household has left after income is spent on standard consumption. Each bank uses a slightly different definition of this standard consumption but it is always above a legally given minimum.

The second step in the mortgage approval process is setting the interest rate. As a basis for the interest rate determination, we consider the mortgage calculator of the bank CSOB at www.csob.cz. There are only two determinants of the interest rates implicitly embedded in this calculator: the loan-to-value ratio (LTVR) and the fixation period for the interest rate. The maturity of the loan only matters if it changes jointly with the fixation period. In October 2010, the interest rate was 4.49 for LTVR $\leq 0.85$ and 5.69 for for LTVR $>0.85$. We implement this rule in our sample as follows. We assume that a household would be interested in buying an apartment of the same size and in the same location as its current rented apartment. We calculate the value of this apartment simply by multiplying its footage by a price per $\mathrm{m}^{2}$ from the Czech Statistical Office. We subtract available savings for each household from the apartment's value and compute LTVR. This LTVR translates into a mortgage interest rate for each household. If the household has sufficient savings to purchase the real estate without a need for the loan, we set the corresponding mortgage rate to zero. The calculator gives us an interest rate

\footnotetext{
${ }^{5}$ In addition, we have considered the so-called family structure, which is the number of children per number of employed adults. This can be viewed as endogenous and we therefore opted simply for the number of persons living in a household. However, the results of our regressions do not change if the family structure replaces the number of household members.
} 
only for the year 2010. For example, a data point for a household from 2006 is used to get the interest rate, which would be charged for a household with the same characteristics in 2010. Clearly, the macroeconomic conditions are different in 2010 as compared to other years. To account for this change, we compute the difference of the mean mortgage interest rate for 1-5 year mortgage rates from the Czech National Bank between a given year and 2010. The rates in percentages are 4, 4.58, 4.92, 5.69, and 4.99 for years 2005-8 and 2010, respectively. We add the difference to rates of all households with a positive LTVR in the given year. For instance, we add 4.00-4.99=-0.99 to mortgage rates in 2005. We employ the thus acquired interest rates in our tenure-choice regressions where they represent the cost of borrowing, which is part of the opportunity cost of staying as a renter of a regulated apartment. For owners, the interest rates reflect savings decreasing below a threshold given by $15 \%$ of the value of the dwelling where they live.

The next explanatory variable is the price of real estate in Kč per $\mathrm{m}^{2}$. The source of the data is CSO. For the surveys before 2006, the coding of regions in the consumer survey corresponds exactly to real estate indices published by the CSO. Only a less detailed coding is available since then. For households which remained in the sample since 2005 this is not a problem. For some households in smaller regions, we can use available information on the size of the population in sub-regions to identify a finer location corresponding to the data from CSO. In addition, we can calculate the price from the maximum rent appreciation (2) for households which stayed in a regulated apartment and the actual rent appreciation equals the legal maximum. There is a handful of observations left in bigger cities and for these we use a price average for the bigger region. The apartment price is likely to be a stationary variable, as indicated by the panel data unit root tests for Czech apartment prices in Zemčík (2011). However, we can see that the price has increased. Figure 1 depicts the Apartment Price Index from CSO (it equals 100 in 2003). The regulated rent appreciation is calculated using equation (2) for households living in apartments with regulated rent. Prior to 2006, we use the actual regulated rent 
appreciation since the deregulation act was not yet passed. After Act 107 took effect, regulated rents appreciated much faster than market rents and the two were converging, as intended by regulation. Table 4 reports average rents in regulated and unregulated apartments. The regulated rents increased by $14 \%$ from 2005 to 2006 since some renters may have agreed on greater rents before Act 107 became effective to avoid potentially greater increases in the future (the Act was approved in March 31, 2006 and became effective on January 1, 2007). Never-the-less, the next increase was even greater in the following year, $18 \%$. The market rents' mean is somewhat misleading for the first year. The mean is likely to be biased upward since we eliminated renters when we were not sure if their rent was regulated or not (recall that an indicator for regulated vs unregulated rent was only introduced in the next year). This left was with renters paying higher rent. We can conclude though that market rents were stagnating or growing at a slower rate than regulated rents.

The next variable of interest is the supply shock in the free rental market measured by the ratio of regulated vs. non-regulated apartments in the household's geographical location. The expected result of rent deregulation is a larger number of apartments on the free rental market (i.e. a shift of the supply curve to the right) in the near future and hence lowered market rents.

\section{Tenure Choice}

In this section, we concentrate on the probability of changing status. For renters, this means the actual purchase of property and for owners the sale of property and switching to renting. This is in contrast to the standard analysis of cross-sectional data where the objective is to predict the current tenure status of households. Let us define a binary response variable $y_{i, t+1}$, which equals one if a household switches its status between years 
$t$ and $t+1$, and zero otherwise. The response probability is given by

$$
\operatorname{Prob}\left(y_{i, t+1}=1 \mid x\right)=G\left(x_{i, t}^{\prime} \beta\right) .
$$

In the case of the probit model, $G$ is the standard normal cumulative distribution function. We also consider the logit model where $G$ is the logistic function and the linear probability model, where $G=x_{i, t}^{\prime} \beta$. The vector of explanatory variables is given by

$$
x_{i, t}=\left(\text { const., } Y_{i t}, \text { age }_{i t}, \text { age }_{i t}^{2}, \text { educ }_{i t}, \text { member } s_{i t}, i_{i t}, P_{i t}, R R A_{i t} \text { or } S S_{i t}\right)^{\prime} .
$$

Estimates of $\beta$ coefficients are calculated by the method of maximum likelihood. The first explanatory variable is the household income $Y_{i t}$, which is a measure of the expected income. Characteristics of the household head such as age and education can themselves affect the tenure decision or they can proxy for income. age $e^{2}$ accounts for life-cycle related effects. For example, income can start declining after reaching a peak at about age 50. Also, households can consider staying in a small rented apartment when they are getting closer to retirement. The variable members reflects a greater need for perceived stability often associated with property ownership, especially for families with children. A higher mortgage interest rate $i_{i t}$ should reduce the probability of a switch to owning. The price of a current household dwelling $P_{i t}$ is a measure of the market price of the household's potential future apartment. For renters of regulated apartments, the legally given regulated rent appreciation $R R A$ should increase the probability of owning property. The supply shock $S S_{i t}$ is relevant for renters of apartments on the free rental market and for owners. The greater the ratio of regulated vs. non-regulated apartments, the more likely it is that market rents will decline in the near future. In this case, renters are less likely to purchase their own apartment and owners are more likely to become renters.

The results of estimation for the parameters of the probit model for renters paying regulated rent are reported in Table 5. We estimate $\beta$ also for the years 2005-2006 for the sake of comparison of the effects of the considered variables before and after adoption of the deregulation act. Income is mostly significant with an always positive coefficient 
estimate, as expected. Coefficients of age and $a g e^{2}$ are positive and negative. Interestingly, the age effects became more pronounced after the change in the law. The opposite is true for education, whose coefficient has a varying sign. age, age $e^{2}$, and educ can serve as a proxy for income and the age-related variables have an explanatory power in addition to income. The estimated coefficient for the number of household members is mostly positive and occasionally significant. The mortgage interest rate coefficient is negative and with one exception significant, in line with our intuition. Our main variables of interest are the real estate price and the regulated rent appreciation. The results provide strong evidence of the impact of rent deregulation on tenure choice. Prior to 2006, higher apartment prices do reduce the probability of a switch to owning but the estimates are insignificant. This is because the benefits of living in an apartment with regulated rents outweigh any effect of the price. The $R R A$ coefficient is insignificant since there is only a small change in the regulated rents and the new law has not yet been adopted. The situation changes dramatically when the deregulation starts. The effects of the real estate price and the regulated rent appreciation are both significant and in accordance with our prior. Higher prices lower the probability of owning and higher regulated rents increase it.

The probit estimates for renters paying market rent are given in Table 6. The estimated income coefficient is always positive and significant. The age-related variables are not significant and with varying signs, which is in contrast with our previous results. The likely reason is that household heads of households in unregulated apartments are about 10 years younger and the variation in their age is smaller than the age of the heads of households in regulated apartments - see Table 2. We therefore exclude them from our remaining regressions as well as education, whose impact does not follow a regular pattern either. The coefficient for members is always significantly positive, which may be due to the stability of owning real estate as compared to renting for the market rent. The coefficient of the interest rate is negative and significant. Our primary focus is again on real estate prices and a measure of the market rent appreciation, represented here by the 
supply shock. First, there does not seem to be any change after deregulation starts. The price is clearly more important to renters on the free market in 2005-2006 as ownership is a closer substitute for them than it is for renters in regulated apartments. The supply shock already matters in this sub-period as well. This is due to implicitly anticipated deregulation, even without an explicit form. As long as the rental market is deregulated some time in the future, the supply shock will play a role in household decisions. Second, both variables negatively affect the probability of switching to owning. The significance of estimates varies. This can be explained by the nature of the relationship between $P$ and $S S$. The real estate price should be related to the market rent (represented by the supply shock). Ceteris paribus, if the market rents increase, households will demand more apartments to own, pushing up their price. Therefore unless there is a strong segmentation of these two markets, there may be collinearity between $P$ and $S S$. We examine this hypothesis by including only one of these variables in our probit model at a time. In such cases, an estimate of at least one of the variables is always significant. The insignificant price in 2007-2008 is likely to be due to a somewhat less precise matching between household region and the corresponding real estate price (see our discussion of this issue in Section 3).

We perform a number of checks to evaluate the robustness of our results. First, we examine the sensitivity to the employed estimation method. Estimating the parameters using logit and linear probability models yields estimation results that are quantitatively and qualitatively similar to the ones reported in Tables 5 and 6 . Second, we experiment with alternates to some of the used key variables. We replace the mortgage interest rate by the total mortgage interest payment for a 25-year loan. We use the net present value of renting a regulated apartment vs. owning one (discussed in detail in the next section) to proxy for the regulated rent appreciation. We also use the price of an apartment as opposed to the unit price. None of these alterations affects our results in any significant manner. 
In addition to studying renters, we estimate the same regression for owners to investigate what affects their decision to switch to renting. The percentage of owners who actually switch to renting is very small (see Table 1). Table 7 reports regression results. Greater income translates into a lower probability of a switch, as intuitively expected. The coefficient estimate is significantly positive in six out of nine cases. Age, age squared and education do not seem to matter for any sub-period. The sign of the coefficient estimate for the number of household members switches after the new act is introduced but the estimate is only once significantly positive. The impact of the mortgage interest rate is interesting. Here it serves as a way to assess households' savings rather than the opportunity cost related to borrowing. Greater rates are associated with lower savings since the mortgage rates are greater for loan-to-value ratios over $85 \%$. Savings actually do not imply significant coefficients if they replace the mortgage rates. We assume this is because the amount of savings matters only below a certain threshold. Therefore greater rates imply a greater probability of selling an apartment and starting to rent but only after the change in the law is introduced. Again, the main variables of interest are the real estate price and the supply shock. Here the timing of deregulation matters less since both variables affect owners only indirectly. The effect of the price is positive and statistically significant since higher prices tempt households to realize capital gains. Greater supply shock implies lower expected rents in the future and increases the probability of a switch to renting. The impact of the two variables tends to be stronger if only one of them is included in the regression due to previously discussed collinearity. Employing logit and linear probability models does not alter the results.

Finally, to account for the possibility that households living in regulated apartments can switch to renting a smaller apartment at the market rent, we use a multinomial probit/logit model where the renters living in regulated apartments can also switch to apartments with market rent in addition to becoming an owner. No clear pattern is identified here, most likely due to the very small number of households which swapped 
paying regulated rent for market rent (see Table 1). This is not a surprising outcome because such a decision is irrational in the context of our econometric model. Regulated rent is typically much lower than market rent for an apartment of the same size, and the moving household would have to have a good reason to abandon the regulated apartment - perhaps to get closer to a hospital or because of conflicts with the current landlord. We do not have information at our disposal to be able to address this particular issue.

The fact that $84 \%$ of renters still paid regulated rent in 2005 even though the communist system had already collapsed in 1989 and that only 5\% switched to owning in 2005-2006 support our conclusion that with rare exceptions, households living in regulated apartments prior to 2006 remained in their regulated apartments. In other words, there are no systemic unobserved characteristics of households which remained renters since the early 1990s. A final issue that may affect our results is privatization. Especially in the 1990s, municipalities tried to off-load the burden of apartments with regulated rents by selling them to tenants for a fraction of the market price. This would reduce the effect of deregulation in our regressions. However, the privatization process was nearly complete by the end of the 1990s. Also, while only $5 \%$ of renters in regulated apartments purchased real estate prior to the deregulation, this percentage increased to 14 and 18\%, respectively, in the two subsequent periods. This increase is likely due to the deregulation. Moreover, some of the switchers prior to 2006 may have switched to owning because they already anticipated the forthcoming deregulation.

\section{$5 \quad$ Property Price Expectations}

In this section, we try to characterize the households expectations for market real estate prices. We focus exclusively on households initially living in apartments with regulated rents since in this case we can express the expected rent appreciation explicitly in terms of real estate price appreciation. In each period, these households can choose to stay 
in the apartment with regulated rent (no switch) or to purchase an apartment of their own (switch). A present value model is used to define rationality. The household choices impose bounds on the real estate price expectations. This approach is new and differs from simply asking households what are their expectations for property prices are. It is also a non-standard use of the present value model, which can be employed to see if the household choices are rational, given their price expectations. Here we assume the households behave rationally and we do not attempt to make their tenure choice conditional on price expectations.

The present value model is in general characterized by the first-order condition from an optimization problem of a risk neutral consumer:

$$
P_{t}=E_{t}\left[\left(P_{t+1}+D_{t+1}\right)\right]
$$

where $P_{t}$ is the price of the household's dwelling and $D_{t}$ is the cash-flow associated with it. If a household decides to purchase real estate (a house or an apartment), the present value of owning is given by:

$$
P V(\text { own })=E_{t}\left[\beta D_{t+1}+\ldots+\beta^{k} D_{t+k}-\beta^{k}\left(\left(1-\tau_{\text {property }}\right) P_{t+k}-L B_{t+k}\right) .\right]
$$

$D_{t+1}, \ldots$ are cash outflows of the household, which take into account tax exemption of mortgage interest rates. We abstract from the possibility that the legal system can change. ${ }^{6}$ $D_{t+1}$ also includes the down payment on the real estate. $\tau_{\text {property }}$ are transaction costs as a portion of the sales price. They consist of the $3 \%$ sales tax and the common $2 \%$ fee for a real estate agent. Real estate agent fees are lower in the Czech Republic, where their services are used less frequently than in the United States and therefore this is probably an upper limit. $\tau_{\text {property }}$ is then $5 \%$ in total. We first set the time of selling property to $k=4$ years, which corresponds to the time when the annual regulated rent reaches $5 \%$ of

\footnotetext{
${ }^{6}$ The system actually did change after the end of our sample period in 2009 when the Czech government introduced the notion of a "super-wage" flat tax. This reduced the tax exemption on mortgage interest payment for households in higher income categories, with the marginal tax rate reduced from $32 \%$ to $15 \%$.
} 
the apartment price. In addition, we consider $k=25$ to account for the possibility that the household resides in the acquired dwelling until it pays off the mortgage. Here we only consider households in which the age of the head less or equal to 50, to abstract from the possibility that a mortgage loan is denied due to the potential death of the creditor. $\beta=0.99$. We assume that $\beta=\frac{1}{1+i_{\text {free }}}$ where $i_{\text {free }}$ is a risk-free rate. We further assume for the sake of simplicity that $\beta$ and hence $i_{\text {free }}$ are constant. $L B_{t+k}$ is the mortgage balance at time $t+k$.

The cash outflow consists of a time-varying part $d_{t}$ and a constant part $\bar{d}$, i.e. $D_{t}=$ $\bar{d}+d_{t} . \bar{d}$ is an annual debt service for the mortgage with monthly compounding. $i_{t}$ is the mortgage rate. Let us define the monthly interest rate $i^{*}=i_{t} / 12$, the number of periods in months $n$, and the present value factor

$$
P V F\left(i_{t}^{*}, n\right)=1 /\left(1+i_{t}^{*}\right)^{n}
$$

The annual mortgage payment is calculated as

$$
\bar{d}=12 L \frac{i_{t}^{*}}{1-P V F\left(i_{t}^{*}, T\right)},
$$

where the loan size $L$ is computed as $P_{t}$ minus the household's current savings. We set $T=25 * 12=300$ months i.e. 25 years. Now we can write $P V($ own $)=E_{t}\left[d_{t}+\beta d_{t+1}+\ldots+\beta^{k} d_{t+k}+\bar{d} \frac{1-\beta^{k+1}}{1-\beta}-\beta^{k}\left(\left(1-\tau_{\text {property }}\right) P_{t+k}-L B_{t+k}\right)\right]$.

Let us further define the number of periods in months $n=12 t$, the loan balance at time $t$ as $L B_{t}$, the principal at time $t$ as $P R I N C I P A L_{t}$, and the annual interest payment during the year $t$ as INTEREST . Note that $L B_{t}=L$. Then

$$
\begin{array}{ll}
L B_{t+j} & =\frac{\bar{d} / 12\left[1-P V F\left(i^{*}, T-12 j\right)\right]}{i^{*}}, \\
\operatorname{PRINCIPAL} L_{t+j} & =L B_{t+j-1}-L B_{t+j}, j=1,2, \ldots, k, \\
\text { INTEREST } & =\bar{d}-P R I N C I P A L_{t+j} .
\end{array}
$$

The time-varying savings from interest payments in the year $t$ are given by

$$
\tau_{\text {income }} \text { INTEREST },
$$


where $\tau_{\text {income }}$ is the income tax, which we set equal to the highest marginal tax rate of $32 \%$.

Real estate prices are assumed to follow an $\mathrm{AR}(1)$ process

$$
P_{t+k}=a P_{t+k-1}+\epsilon_{t+k}=\ldots=a^{k} P_{t}+\sum_{i=0}^{k-1} a^{k-1-i} \epsilon_{t+i+1}
$$

and $E_{t} P_{t+k}=a^{k} P_{t}$. This assumption reflects autocorrelation present in first-differenced property prices in OECD countries demonstrated, for example, in Englund and Ioannides (1997). This result implies that the current price level depends on the price level in the previous period. Also, this specification corresponds directly to testing for unit roots in levels - see for instance Mikhed and Zemčík (2009) for the US data and Zemčík (2011) for the Czech data. Real estate researchers are interested in knowing whether $a \geq 1$, in which case there is a unit root, the real estate price process is non-stationary, and there is a rational bubble. The bubble is rational since this price process does not violate equation (5) that represents first-order conditions of the household optimization problem. Equation (9) simplifies somewhat to

$$
P V(\text { own })=d_{t}+\beta d_{t+1}+\ldots+\beta^{k} d_{t+k}+\bar{d} \frac{1-\beta^{k+1}}{1-\beta}-\beta^{k}\left((1-\tau) a^{k} P_{t}-L B_{t+k}\right)
$$

The expectation is removed from this equation since the only uncertainty stems from the future price in our set-up. The time varying cash-flows are predictable because they are determined at time $t$ assuming the legal framework for real estate does not change. We do not take into account the possibility of a default on mortgage payments by the household.

We plan to draw information about $a$ from the household decisions to rent vs to own. To filter out price expectations, we make use of the official formulae used to calculate the target rent and the maximum rent appreciation - see equations (1) and (2), respectively. We set $t=2006$. Noting that we need the annual rent, we can write:

$$
E_{t}\left[R_{t+1}\right]=\left(\frac{c P_{t}}{R_{t}}\right)^{1 / 4} R_{t}=\left(c P_{t}\right)^{1 / 4} R_{t}^{3 / 4}
$$


Using the process for the real estate price (12), we can also see that

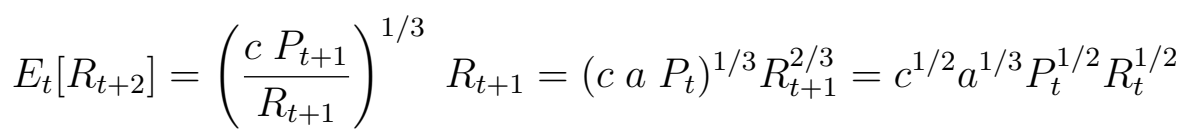

and

$$
E_{t} R_{t+3}=c^{3 / 4} a^{7 / 6} P_{t}^{3 / 4} R_{t}^{1 / 4}
$$

From this point on, the rent should be equal to the target rent, i.e.

$$
E_{t} R_{t+3+i}=c a^{3+i} P_{t}, \quad i=1,2, \ldots
$$

Now we can determine the present value of living in an apartment with regulated rent

$$
\begin{aligned}
P V(\text { reg })= & E_{t}\left[R_{t}+\beta\left(c P_{t}\right)^{1 / 4} R_{t}^{3 / 4}+\beta^{2} c^{1 / 2} a^{1 / 3} P_{t}^{1 / 2} R_{t}^{1 / 2}+\beta^{3} c^{3 / 4} a^{7 / 6} P_{t}^{3 / 4} R_{t}^{1 / 4}\right. \\
& \left.+\beta^{4} c a^{4} P_{t}+\ldots+\beta^{m} c a^{m} P_{t}\right]
\end{aligned}
$$

where $m$ is the life-expectancy of the household head in the Czech Republic. According to the data from the Czech Statistical Office in 2004, the life expectancy was 73.1 years for 15-year old males and 79.6 for 15-year old females, respectively. We set $m$ to be 75 minus the current age of the household head. This in part reflects more households with male heads who are older than 15 years (the available data then lists this information for 45year olds). The present value of interest on the savings not used to pay a down payment is zero since we set the discount factor $\beta$ using the risk-free interest rate. Expression (18) can be further simplified to

$$
\begin{aligned}
P V(\text { reg })= & R_{t}+\beta\left(c P_{t}\right)^{1 / 4} R_{t}^{3 / 4}+\beta^{2} c^{1 / 2} a^{1 / 3} P_{t}^{1 / 2} R_{t}^{1 / 2}+\beta^{3} c^{3 / 4} a^{7 / 6} P_{t}^{3 / 4} R_{t}^{1 / 4} \\
& +\beta^{4} c a^{4} P_{t} \frac{1-(\beta a)^{m-3}}{1-\beta a} .
\end{aligned}
$$

The final step of comparison between owning vs. renting an apartment is calculation of the Net Present Value (NPV):

$$
N P V=P V(\text { reg })-P V(\text { own })
$$

which is a function of $a$, the autoregressive parameter of the real estate price process. This parameter characterizes expectations of the household. Renters living in an apartment 
with regulated rent should have NPV greater than zero if they purchased an apartment and lower than zero otherwise. We solve numerically for $a$, which sets NPV to 0 for all renters in regulated apartments, i.e. we find $a^{*}$ such that $\operatorname{NPV}\left(a^{*}\right)=0$. If households decide to purchase real estate, $a^{*}$ is a lower bound on their price expectation and if they stay in the rental apartment, then $a^{*}$ is an upper bound on their price expectation.

Our results are summarized in Table 8. We calculate the distribution of $a^{*}$ for households which shifted from renting to owning and for those which did not. We do this for all three sub-periods, i.e. 2005-2006, 2006-2007, and 2007-2008, respectively. The first sub-period serves as a control group since the rent regulation law was effective only since 2006, though there may have been some anticipation of the law passing through the Czech parliament. The present value model fits the data worse in the first sub-period because in some cases there was no interest rate, which would make NPV positive for non-shifters. These households by definition cannot be rational according to the present value model and we eliminated them from our further calculations. No such case has been found for the other two sub-periods. We have also tested for equality of means using a standard t-test and a Welch F-test, which accounts for potentially differing variances. There are no meaningful patterns emerging either from a comparison between shifters and non-shifters within a sample period nor from a comparison of the same groups across time.

The appreciation means are fairly reasonable as compared with the actual price growth though non-shifters seem to be more conservative with their upper bound on growth lower than the realized growth. This may reflect an element of surprise in increasing real estate prices after 2006, probably due to changing fundamentals. ${ }^{7}$ Figure 1 indicates a period of decline in apartment prices from 2003 to 2005. This in part occurred due to a public expectation of rapid increases in 2004, which was the year the Czech Republic joined the European Union. The prices increased prior to 2004 due to this expectation and

\footnotetext{
${ }^{7}$ For example, according to the Czech National Bank, the volume of mortgages for apartment purchases grew by $37.9 \%$ between 2006 and 2007 and by $17.5 \%$ between 2007 and 2008. Also, the real GDP increased by $6.1 \%$ and $2.5 \%$ in our two sub-samples.
} 
then stagnated; the accelerated growth starting in 2006 therefore could have come as a surprise. The household expectations in any case do not appear to be irrationally high as often occurs when surveys are used. To gain additional insights, we tabulate the empirical distribution of the expected growth of apartment prices for $\mathrm{k}=25$ in Figure 2 . We choose $\mathrm{k}=25$ since the present value model implies values of growth closer to their ex post realizations and it is more likely that households do not buy apartments for purely speculative reasons but instead intend to keep them for an extended period. The most frequent values for non-shifters tend to be the higher ones at the right-hand side of the histogram. The lowest reported values for shifters are greater than the ones for nonshifters since 2006, suggesting again a somewhat greater optimism among the shifters.

\section{Summary}

Rent deregulation in the Czech Republic is a natural experiment where regulated rents explicitly reflect real estate prices. This dependence induces predictability of regulated rent appreciation, which can be usefully exploited. The impact of deregulation is studied using unique household consumption survey data. The advantage of this dataset is the possibility of recording actual households' tenure choices due to the fact that only $25 \%$ of the sample is changed every year.

Our first objective is the analysis of the impact of rent deregulation in the Czech Republic on the tenure choice of households. We control for household characteristics such as income, age, education, and the number of household members. The real estate price and expected mortgage interest rates predictably lower the probability of owning for all renters. Regulated rent appreciation does in fact increase the probability of a real estate purchase for households currently living in rent-controlled apartments. The households in unregulated apartments, meanwhile, anticipate lower market rents. This is because 
the supply on the free rental market is going to increase due to regulated apartments becoming unregulated in the near future. This effect implies a lower probability of owning for free market renters. For owners, lower savings, greater prices, and greater supply shock increase the frequency of renting. Deregulation makes it more likely for mostly middleaged households in regulated apartments to seek their own property. Owners who are older more frequently switch to renting due to expected lower rents. The deregulation process therefore makes the tenure choices related to the life cycle of households smoother.

The second objective of the paper is deduction of real estate price expectations using present value analysis for households in regulated apartments. We assume that the price process is $\mathrm{AR}(1)$. The ex-post appreciation was $9.6 \%$ from 2006 and 2007 and $12.9 \%$ from 2007 to 2008, respectively. We can solve for the real estate price appreciation, which makes the net present value (NPV) of renting vs owning zero. The net present value increases if the price appreciation increases. Therefore, the appreciation making NPV equal to zero imposes an upper limit on households opting to remain in regulated apartments to keep their choice rational. This upper limit is closer to the actual appreciation when we assume that households only sell their property after paying off their mortgages with a maturity of 25 years. It is $1.8 \%$ for the sub-period $2006-2007$ and $2.3 \%$ for the sub-period 2007-2008, respectively. Similarly, the appreciation forms a lower bound for households that have become owners. This lower bound is $2.2 \%$ for both sub-periods after 2006 .

These results suggest that household expectations were fairly conservative. This may be either because the expectations derived from actual choices are more realistic than those based on surveys or because of the specificity of the Czech real estate market. In either case, the rising prices were more likely to be due to underlying fundamentals, i.e. demand and supply factors other than expectations. 


\section{References}

Annas, A., "Rent Control with Matching Economies: A Model of European Housing Market Regulation, Journal of Real Estate Finance and Economics, 15(1), p 11137, 1997.

Beck,T., Kibuuka, K., and Tiongson, E. , "Mortgage Finance in Central and Eastern Europe: Opportunity or Burden?" World Bank Policy Research Working Paper No $5202,2010$.

Case, K.E., and Shiller, R.J., "Is There a Bubble in the Housing Market?" Cowles Foundation Paper No. 1089, 2004.

Clayton, J., "Are Housing Price Cycles Driven by Irrational Expectations?" Journal of Real Estate Finance and Economics 14(3), 341-363, 1997.

Englund, P. and Ioannides, Y. M., "House Price Dynamics: An International Empirical Perspective," Journal of Housing Economics 6, 119-136, 1997.

Li, W. and Yao, R., "The Life-Cycle Effects of House Price Shocks," Federal Reserve Bank of Philadelphia Working Paper No. 05-7, 2005.

Lux, M., "Social housing in the Czech republic, Poland and Slovakia," European Journal of Housing Policy 1(2), p 189-209, 2001.

Lux, M., and Sunega, P., "Modelovani rovnovazme urovne najemneho a dusledku aplikace vybranych nastroju bytove politiky," Finance a Uver, 53(1-2), p 31-59, 2003.

Lux M., Sunega, P., Kostelecký, T., and Čermák, D., "Housing Standards 2002/03 Financial Affordability and Attitudes to Housing," Prague: Institute of Sociology, Academy of Sciences of the Czech Republic, 2003.

Mikhed, V. and Zemčík, P., "Testing for Bubbles in Housing Markets: A Panel Data Approach," Journal of Real Estate Finance and Economics 38, 366-386, 2009.

Moon, C., and Rapaport, C., "Rent Regulation and Housing Vacancies: The New York City Experience, Journal of Economic Theory and Econometrics, 3(1), p 75-102, 1997.

Munch, J., and Svarer, M., "Rent Control and Tenancy Duration, Department of Economics, University of Aarhus, Working Paper No. 24, 2003. 
Raess, P., and Von Ungern-Sternberg. T., "A Model of Regulation in the Rental Housing Market," Regional Science and Urban Economics, 32(4), p 475-500, 2002.

Roistacher, E., Rent Regulation in New York City: Simulating Decontrol Options, Journal of Housing Economics, Vol 2, p 107-138, 1992.

Simmons-Mosley, T., and Malpezzi, S., "Household Mobility in New York City's Regulated Rental Housing Market, Journal of Housing Economics 15(1), p 38-62, 2006.

Van der Klaauw, B., and Kock, U., "Evaluating Dutch Housing Market Regulation, Tinbergen Institute Discussion Papers, 99-007/3, 1999.

Zemčík, P., "Is There a Real Estate Bubble in the Czech Republic?" Forthcoming in the Czech Journal of Economics and Finance, 2011. 
Figure 1: Apartment Price Index from the Czech Statistical Office (equals 100 in 2003)

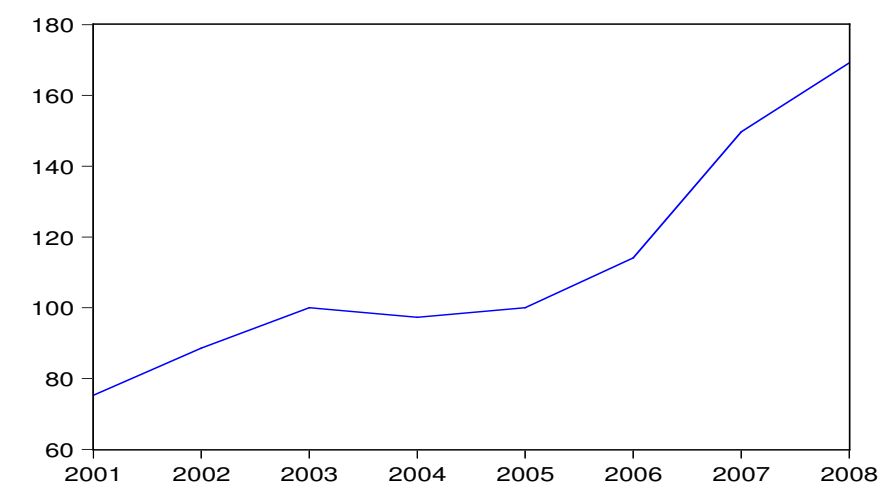


Figure 2: Expectations of Real Estate Price Appreciation for $\mathrm{k}=25$

\section{Notes}

1) switch refers to those households that purchased property. no switch denotes households that stayed in regulated apartments.

2) $k=25$ are number of years of holding property before it is sold.
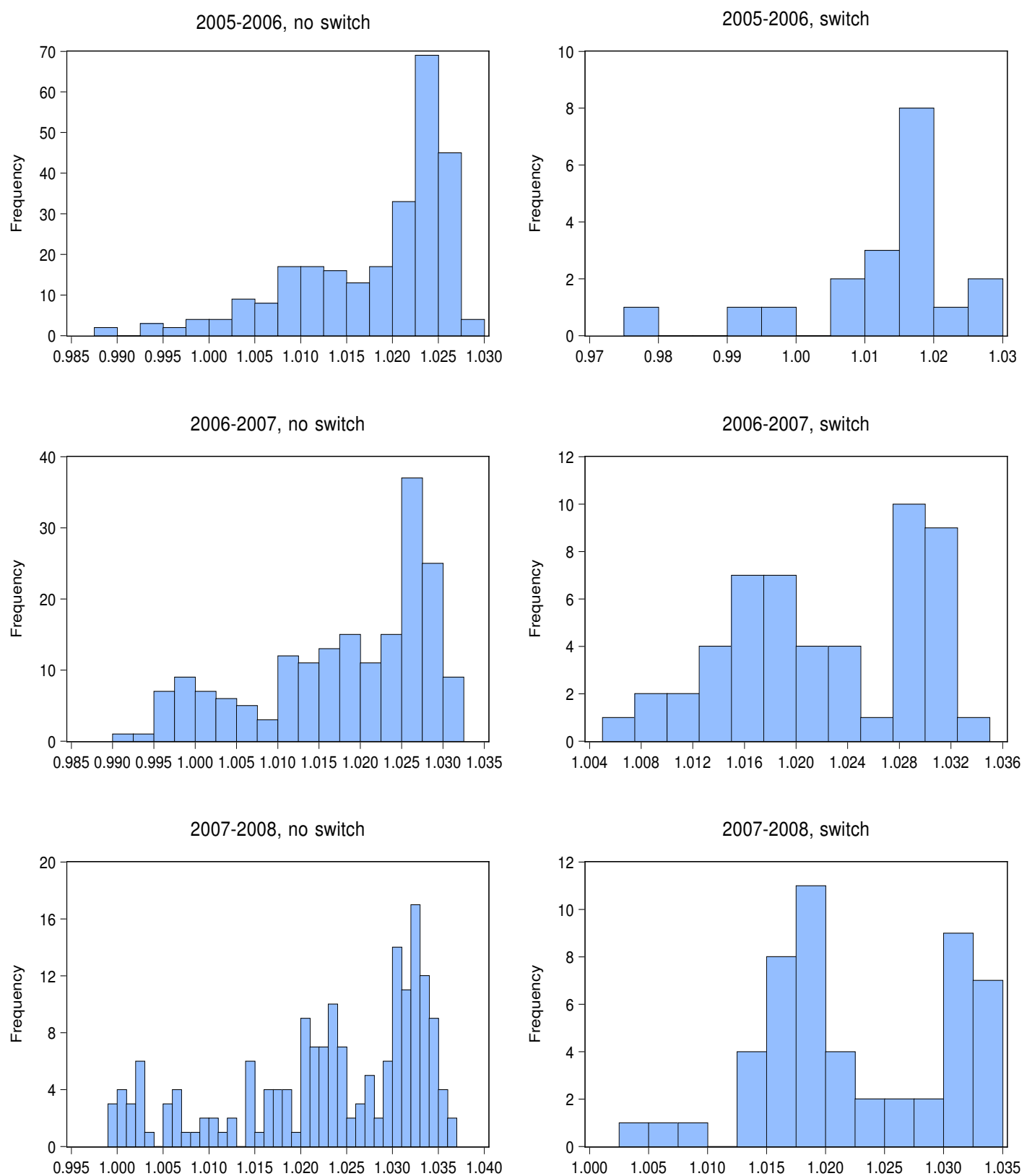
Table 1: Household Status and Sample Size

Notes:

There are three types of a status: renters living in apartments with regulated rents, renters living in apartments with market rents, and owners living in their own apartments. Renters paying regulated rents can become owners or rent for the market rent. Renters paying market rents can become owners. Owners can switch to renting for the market rent.

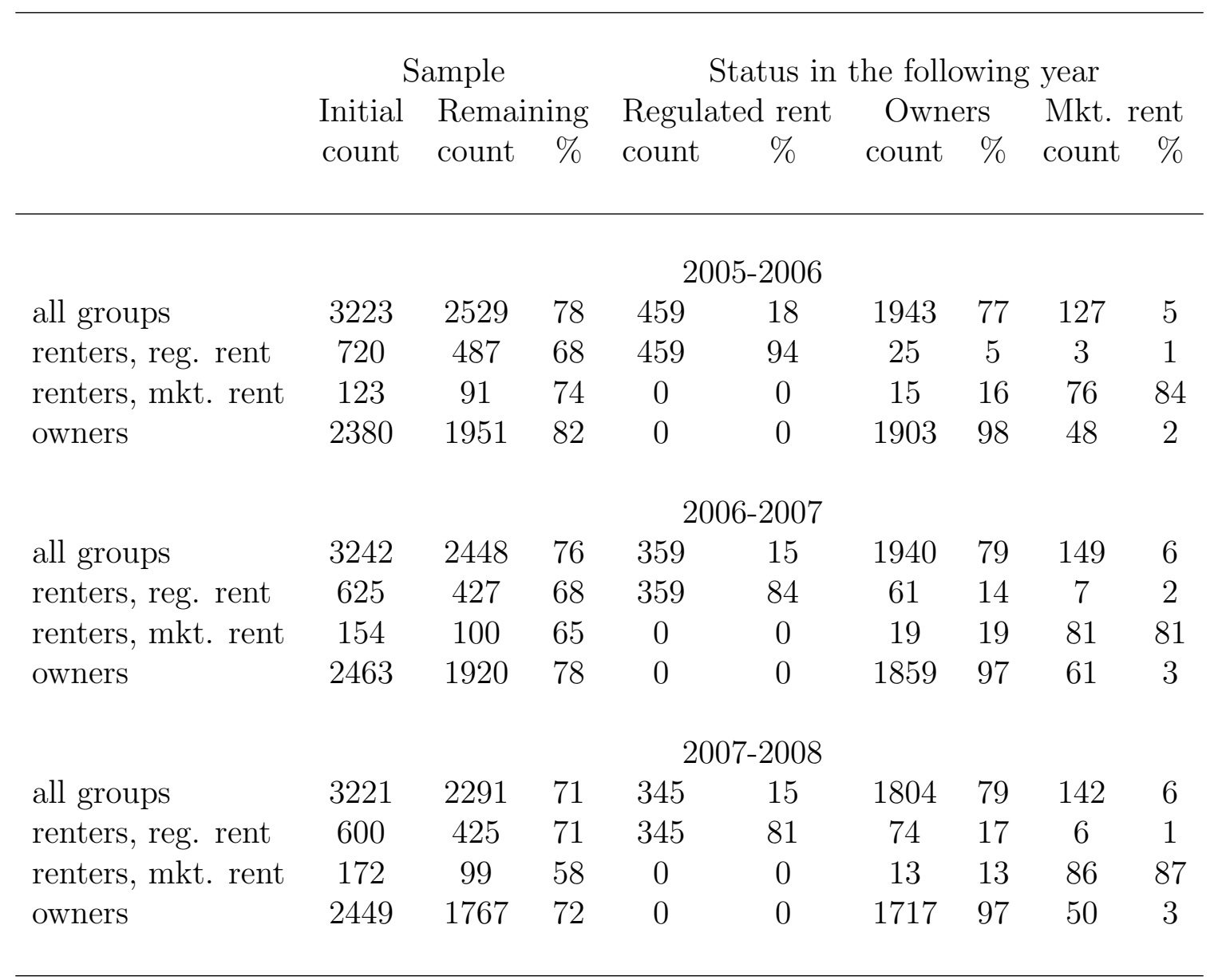


Notes: $Y$ is the monthly household income per person; age is the age of the household head in years; educ is the education of the household head in years; members is the number of household members; $i$ is the mortgage interest rate to be paid for a loan covering up to LTVR \% of the value for a household apartment; $P$ is the regional real estate price in Kč per $\mathrm{m}^{2} ; R R A$ is the regulated rent appreciation given per $\mathrm{m}^{2}$ in $\%$ - it is the actual appreciation for the period 2005-2006 and the legally given maximum for the subsequent periods; and $S S$ is the supply shock, i.e. the ratio in \% of regulated to non-regulated apartments in the households' location.

\begin{tabular}{|c|c|c|c|c|c|c|c|c|}
\hline & $Y$ & age & $e d u c$ & members & $i$ & $P$ & $R R A$ & $S S$ \\
\hline & \multicolumn{8}{|c|}{ 2005-2006, regulated rents, 484 obs. } \\
\hline mean & 19,304 & 46.07 & 12.01 & 2.44 & 4.14 & 11,887 & 2.37 & \\
\hline $\min$ & 4,786 & 18.00 & 9.00 & 1.00 & 0.00 & 3,729 & 0.00 & \\
\hline $\max$ & 68,550 & 87.00 & 20.00 & 6.00 & 4.70 & 4,1026 & 5.33 & \\
\hline \multirow[t]{2}{*}{ st. dev. } & 11,047 & 14.79 & 2.72 & 1.19 & 0.90 & 7,260 & 0.99 & \\
\hline & \multicolumn{8}{|c|}{ 2005-2006, mkt. rents, 91 obs. } \\
\hline mean & 18,385 & 35.56 & 11.91 & 2.45 & 3.95 & 11,725 & & 21.12 \\
\hline $\min$ & 6,963 & 21.00 & 9.00 & 1.00 & 0.00 & 3,729 & & 9.50 \\
\hline $\max$ & 55,748 & 77.00 & 20.00 & 6.00 & 4.70 & 41,076 & & 36.50 \\
\hline \multirow[t]{2}{*}{ st. dev. } & 8,261 & 11.53 & 2.43 & 1.14 & 0.94 & 6,798 & & 10.00 \\
\hline & \multicolumn{8}{|c|}{ 2006-2007, regulated rents, 420 obs. } \\
\hline mean & 20,937 & 47.84 & 12.10 & 2.38 & 4.41 & 12,255 & 19.80 & \\
\hline $\min$ & 4,620 & 21.00 & 9.00 & 1.00 & 0.00 & 3,520 & 0.00 & \\
\hline $\max$ & 78,852 & 84.00 & 20.00 & 6.00 & 5.28 & 44,275 & 91.69 & \\
\hline \multirow[t]{2}{*}{ st. dev. } & 11,497 & 14.15 & 2.85 & 1.18 & 1.37 & 7,857 & 17.06 & \\
\hline & \multicolumn{8}{|c|}{ 2006-2007, mkt. rents, 100 obs. } \\
\hline mean & 19,208 & 35.62 & 12.05 & 2.22 & 3.87 & 13,091 & & 21.38 \\
\hline $\min$ & 4,783 & 21.00 & 9.00 & 1.00 & 0.00 & 4,014 & & 6.50 \\
\hline $\max$ & 60,690 & 81.00 & 20.00 & 5.00 & 5.28 & 44,725 & & 36.00 \\
\hline \multirow[t]{2}{*}{ st. dev. } & 10,813 & 10.88 & 2.82 & 1.09 & 1.84 & 10,521 & & 10.69 \\
\hline & \multicolumn{8}{|c|}{ 2007-2008, regulated rents, 419 obs. } \\
\hline mean & 22,636 & 48.86 & 12.23 & 2.35 & 4.81 & 13,427 & 24.19 & \\
\hline $\min$ & 4,215 & 23.00 & 9.00 & 1.00 & 0.00 & 3,824 & 0.00 & \\
\hline $\max$ & 139,027 & 90.00 & 20.00 & 6.00 & 5.62 & 45,537 & 96.00 & \\
\hline \multirow[t]{2}{*}{ st. dev. } & 13668 & 14.05 & 2.98 & 1.21 & 1.39 & 8,518 & 20.77 & \\
\hline & \multicolumn{8}{|c|}{ 2007-2008, mkt. rents, 100 obs. } \\
\hline mean & 19,849 & 38.54 & 11.84 & 2.16 & 4.43 & 14,314 & & 22.98 \\
\hline $\min$ & 4,005 & 24.00 & 9.00 & 1.00 & 0.00 & 3,824 & & 6.00 \\
\hline $\max$ & 51,790 & 82.00 & 20.00 & 5.00 & 5.62 & 45,337 & & 36.00 \\
\hline st. dev. & 9,696 & 13.03 & 2.85 & 1.10 & 1.60 & 11,394 & & 10.33 \\
\hline
\end{tabular}


Table 3: Summary Statistics for Owners

Notes:

See Table 2 for definitions of variables.

\begin{tabular}{|c|c|c|c|c|c|c|c|}
\hline & $Y$ & age & $e d u c$ & members & $i$ & $P$ & $S S$ \\
\hline & \multicolumn{7}{|c|}{ 2005-2006, 1951 obs. } \\
\hline mean & 21,633 & 49.57 & 12.15 & 2.58 & 4.02 & 9,999 & 16.49 \\
\hline $\min$ & 4,591 & 22.00 & 9.00 & 1.00 & 0.00 & 3,729 & 7.00 \\
\hline $\max$ & 125,425 & 90.00 & 20.00 & 11.00 & 4.70 & 41,076 & 36.50 \\
\hline \multirow[t]{2}{*}{ st.dev } & 10,891 & 13.72 & 2.97 & 1.21 & 0.78 & 5,039 & 8.06 \\
\hline & \multicolumn{7}{|c|}{ 2006-2007, 1920 obs. } \\
\hline mean & 23,571 & 50.03 & 12.14 & 2.54 & 4.32 & 9,249 & 15.02 \\
\hline $\min$ & 3,776 & 20.00 & 9.00 & 1.00 & 0.00 & 3,520 & 6.50 \\
\hline $\max$ & 145,401 & 88.00 & 20.00 & 9.00 & 5.28 & 44,275 & 36.00 \\
\hline \multirow[t]{2}{*}{ st.dev } & 12,355 & 13.98 & 2.99 & 1.15 & 1.18 & 6,441 & 9.66 \\
\hline & \multicolumn{7}{|c|}{ 2007-2008, 1767 obs. } \\
\hline mean & 25,996 & 50.68 & 12.18 & 2.51 & 4.58 & 10,241 & 14.02 \\
\hline $\min$ & 4,159 & 20.00 & 9.00 & 1.00 & 0.00 & 3,824 & 5.50 \\
\hline $\max$ & 208,187 & 89.00 & 20.00 & 8.00 & 5.62 & 45,537 & 35.00 \\
\hline st.dev & 14,235 & 13.77 & 3.04 & 1.15 & 1.25 & 7,120 & 9.38 \\
\hline
\end{tabular}

Table 4: Rents

Notes:

Reported monthly rents in Kč per $\mathrm{m}^{2}$ are from the first year of each period.

\begin{tabular}{ccc}
\hline Period & Regulated rents & Mkt. rents \\
\hline $2005-6$ & 21.65 & 76.85 \\
$2006-7$ & 24.72 & 58.78 \\
$2007-8$ & 29.17 & 62.84 \\
\hline
\end{tabular}




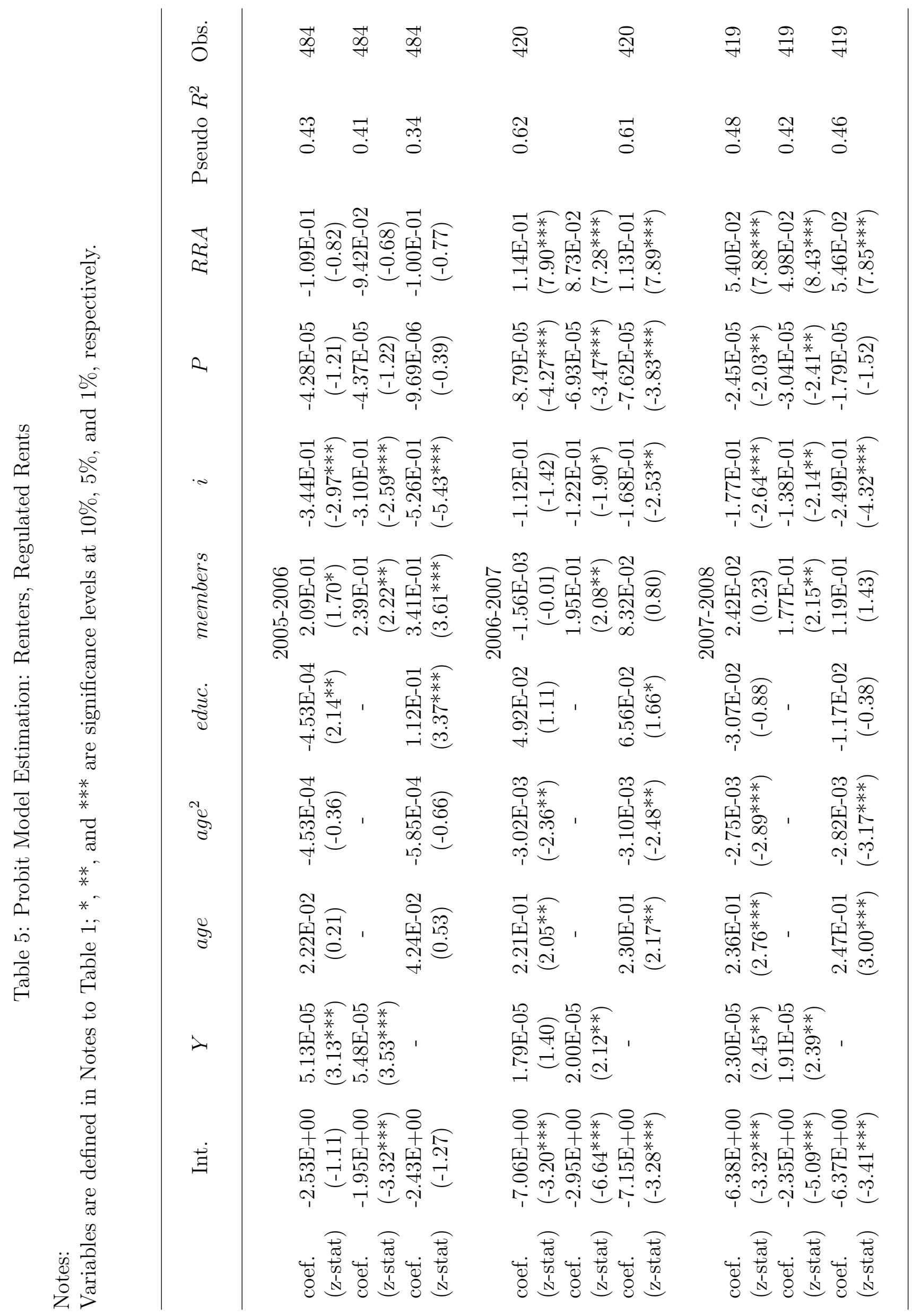




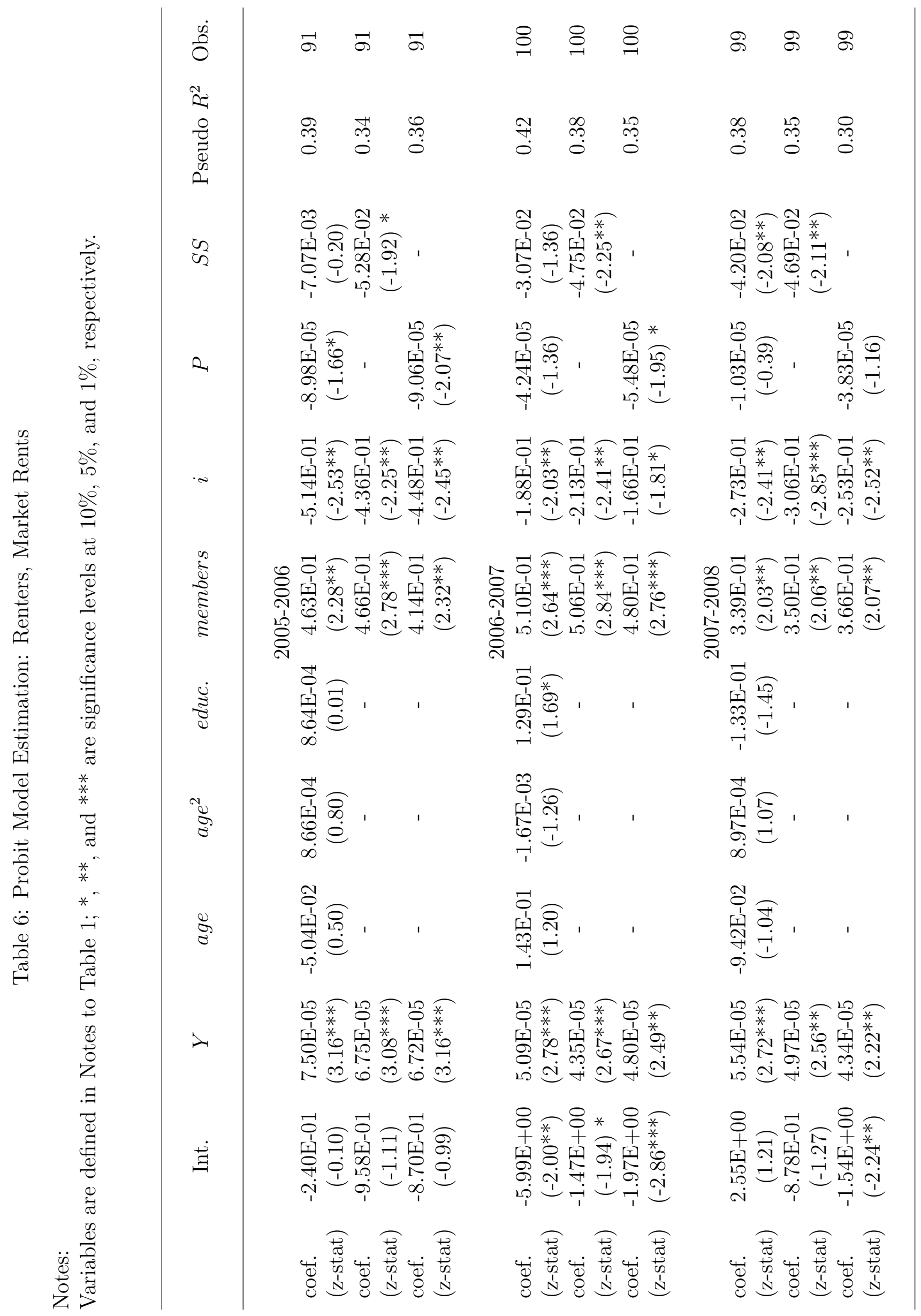




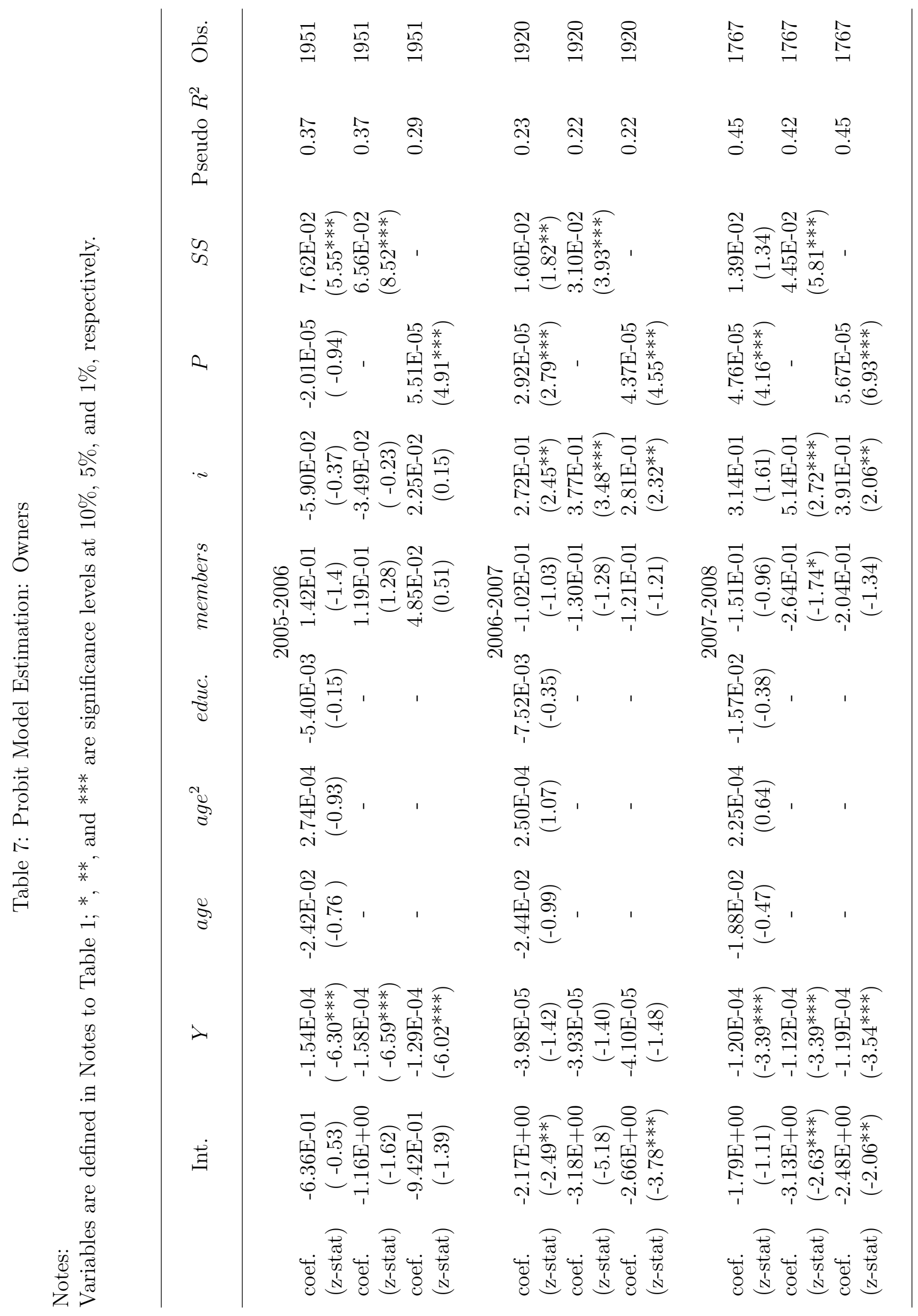


Table 8: Real Estate Price Expectations

Notes:

1) Actual appreciation is the actual gross price increase of prices of all apartments with a regulated rent based on regional market prices.

2) switch refers to those households that purchased property. no switch denotes households that stayed in the regulated apartments.

3) $k=4,25$ are number of years of holding property before it is sold.

\begin{tabular}{lccc}
\hline & $2005-2006$ & $2006-2007$ & $2007-2008$ \\
\hline $\begin{array}{l}\text { Actual } \\
\text { appreciation }\end{array}$ & 1.0310 & 1.0956 & 1.1291 \\
\hline
\end{tabular}

no switch switch no switch switch no switch switch

\begin{tabular}{lllllll}
\multicolumn{7}{c}{$\mathrm{k}=4$} \\
Mean & 0.9944 & 0.9884 & 0.9933 & 1.0099 & 1.0169 & 1.0083 \\
Median & 0.9993 & 0.9907 & 0.9998 & 1.0083 & 1.0197 & 1.0072 \\
Maximum & 1.0225 & 1.0150 & 1.0319 & 1.0354 & 1.0487 & 1.0379 \\
Minimum & 0.9002 & 0.9193 & 0.9225 & 0.9828 & 0.9855 & 0.9675 \\
Std. Dev. & 0.0198 & 0.0228 & 0.0220 & 0.0135 & 0.0156 & 0.0161 \\
& \multicolumn{7}{c}{$\mathrm{k}=25$} \\
Mean & 1.0180 & 1.0125 & 1.0180 & 1.0223 & 1.0230 & 1.0224 \\
Median & 1.0218 & 1.0159 & 1.0204 & 1.0209 & 1.0246 & 1.0201 \\
Maximum & 1.0284 & 1.0261 & 1.0322 & 1.0327 & 1.0360 & 1.0343 \\
Minimum & 0.9887 & 0.9776 & 0.9922 & 1.0073 & 0.9996 & 1.0031 \\
Std. Dev. & 0.0084 & 0.0119 & 0.0105 & 0.0073 & 0.0104 & 0.0079 \\
& & & & & &
\end{tabular}




\section{Working Paper Series}

ISSN 1211-3298

Registration No. (Ministry of Culture): E 19443

Individual researchers, as well as the on-line and printed versions of the CERGE-EI Working Papers (including their dissemination) were supported from the following institutional grants:

- Economic Aspects of EU and EMU Entry [Ekonomické aspekty vstupu do Evropské unie a Evropské měnové unie], No. AVOZ70850503, (2005-2011);

- Economic Impact of European Integration on the Czech Republic [Ekonomické dopady evropské integrace na ČR], No. MSM0021620846, (2005-2011);

Specific research support and/or other grants the researchers/publications benefited from are acknowledged at the beginning of the Paper.

(c) Ashot Tsharakyan, Petr Zemčík, 2011

All rights reserved. No part of this publication may be reproduced, stored in a retrieval system or transmitted in any form or by any means, electronic, mechanical or photocopying, recording, or otherwise without the prior permission of the publisher.

Published by

Charles University in Prague, Center for Economic Research and Graduate Education (CERGE) and

Economics Institute ASCR, v. v. i. (EI)

CERGE-EI, Politických vězňů 7, 11121 Prague 1, tel.: +420 224005 153, Czech Republic.

Printed by CERGE-EI, Prague

Subscription: CERGE-EI homepage: http://www.cerge-ei.cz

Phone: + 420224005153

Email: office@cerge-ei.cz

Web: http://www.cerge-ei.cz

Editor: Michal Kejak

Editorial board: Jan Kmenta, Randall Filer, Petr Zemčík

The paper is available online at http://www.cerge-ei.cz/publications/working_papers/.

ISBN 978-80-7343-231-7 (Univerzita Karlova. Centrum pro ekonomický výzkum a doktorské studium)

ISBN 978-80-7344-221-7 (Národohospodářský ústav AV ČR, v. v. i.) 
CERGE-EI

P.O.BOX 882

Politických vězňů 7

11121 Praha 1

Czech Republic http://www.cerge-ei.cz 